\title{
COMPARATIVE STUDY REGARDING THE RESISTANCE OF WET-WHITE AND WET-BLUE LEATHER TO THE GROWTH OF FUNGI
}

\author{
STUDIU COMPARATIV PRIVIND REZISTENTA PIEILOR WET-WHITE ŞI WET-BLUE LA CREŞTEREA \\ MUCEGAIULUI
}

\author{
Corina CHIRILÄ", Viorica DESELNICU, Marian CRUDU \\ INCDTP - Division: Leather and Footwear Research Institute Bucharest, 93 Ion Minulescu st., sector 3, RO-031215 Bucharest, e-mail: \\ corina.chirila@icpi.ro
}

\section{COMPARATIVE STUDY REGARDING THE RESISTANCE OF WET-WHITE AND WET-BLUE LEATHER TO THE GROWTH OF FUNGI}

ABSTRACT. Both tanned and finished leather may be damaged by fungi from Aspergillus flavus and Aspergillus niger, Trichoderma viride, Penicillium glaucom and Penicillium cyclopium, and Paecilomyces variotii species which irreversibly damage leather through the enzymes (collagenases, lipases and proteases) they produce. Fungi grow quickly under high humidity conditions and temperatures ranging between 25 and $30^{\circ} \mathrm{C}$. This paper presents a comparative study regarding the fungal resistance of wet-blue (chromium-tanned) leather, wet-white leather tanned with titanium-aluminium-based compounds and wet-white leather tanned with resorcinol-oxazolidine. The study was performed according to ASTM Standard D 4576 - 08(2013) - Test Method for Mold Growth Resistance of Wet Blue. Conclusions of this study about mould growth resistance are drawn from the results obtained for a period of 28 days. It has been concluded by this study that no leather type is completely resistant to fungal attack. Wet-blue leather is highly susceptible to fungal attack of Aspergillus niger and Aspergillus flavus; Trichoderma viride and Mucor pusillus species do not grow on chromium-tanned wet-blue leather. Wet-white leather tanned with Ti-Al is attacked by all types of fungi studied. Wet-white leather tanned with resorcinol-oxazolidine is attacked by Aspergillus niger and Mucor pusillus, but inhibit the growth of moulds from the Aspergillus oryzae and Trichoderma viride species. This type of leather may also be damaged by moulds from the Penicillium genus.

KEY WORDS: wet blue, wet white, fungi resistance

\section{STUDIU COMPARATIV PRIVIND REZISTENTA PIEILOR WET-WHITE ŞI WET-BLUE LA CREŞTEREA MUCEGAIULUI}

REZUMAT. Atât pieile tăbăcite, cât şi pieile finisate pot fi deteriorate de mucegaiuri din speciile Aspergillus flavus şi Aspergillus niger, Trichoderma viride, Penicillium glaucom şi Penicillium cyclopium şi Paecilomyces variotii care degradează în mod ireversibil pielea prin enzimele (colagenaze, lipaze şi proteaze) pe care le produc. Mucegaiurile au o creştere rapidă în condiţii de umiditate ridicată şi temperaturi între 25 şi $30^{\circ} \mathrm{C}$. Prezenta lucrare prezintă un studiu comparativ privind rezistenţa la mucegaiuri a pieilor wet-blue (tăbăcite cu crom), a pieilor wet-white tăbăcite cu compuşi pe bază de titan-aluminiu şi a pieilor wet-white tăbăcite cu rezorcinăoxazolidină. Studiul a fost efectuat conform standardului ASTM D 4576-08 (2013) - Metodă de testare a rezistenţei la mucegai a pieilor wet-blue. Concluziile acestui studiu s-au bazat pe rezultatele obţinute pentru o perioadă de 28 de zile. În urma acestui studiu s-a ajuns la concluzia că niciun tip de piele nu este complet rezistent la atacul fungic. Pieile wet-blue sunt foarte sensibile la atacul mucegaiurilor Aspergillus niger şi Aspergillus flavus; speciile Trichoderma viride şi Mucor pusillus nu se dezvoltă pe pieile wet-blue tăbăcite cu crom. Pieile wet-white tăbăcite cu Ti-Al sunt atacate de toate tipurile de fungi luate în studiu. Pieile wet-white tăbăcite cu rezorcină-oxazolidină sunt atacate de Aspergillus niger şi Mucor pusillus, dar inhibă dezvoltarea mucegaiurilor din speciile Aspergillus oryzae şi Trichoderma viride. Acest tip de piei poate fi deteriorat şi de mucegaiuri din genul Penicillium.

CUVINTE CHEIE: wet blue, wet white, rezistenţă la mucegai

\section{ÉTUDE COMPARATIVE SUR LA RÉSISTANCE DU CUIR WET-BLUE ET WET-WHITE À LA CROISSANCE DES MOISISSURES}

RÉSUMÉ. Les cuirs tannés et finis peuvent être endommagés par les moisissures des espèces Aspergillus flavus et Aspergillus niger, Trichoderma viride, Penicillium glaucom, Penicillium cyclopium et Paecilomyces variotii qui dégradent le cuir de manière irréversible par les enzymes (les collagénases, les lipases et les protéases) qu'elles produisent. Les moisissures ont une croissance rapide dans des conditions de forte humidité et des températures entre 25 et $30^{\circ} \mathrm{C}$. Cet article présente une étude comparative sur la résistance à la moisissure du cuir wet-blue (tanné au chrome), du cuir wet-white tanné aux composés de titane et d'aluminium et du cuir wet-white tanné au résorcinol-oxazolidine. L'étude a été réalisée selon la norme ASTM D 4576-08 (2013) - Méthode d'essai de résistance à la moisissure du cuir wetblue. Les conclusions de cette étude ont été basées sur des résultats obtenus pendant une période de 28 jours. Dans cette étude, on a conclu qu'aucun type de peau n'est complètement résistant à l'attaque des moisissures. Les cuirs wet-blue sont très sensibles aux attaques des moisissures Aspergillus niger et Aspergillus flavus; les espèces de Trichoderma viride et Mucor pusillus ne croissent pas sur le cuir wet-blue tanné au chrome. Les cuirs tannés avec du Ti-Al à l'état wet-white sont attaqués par toutes les moisissures étudiées. Les cuirs tannés avec du résorcinol-oxazolidine à l'état wet-white sont attaqués par Aspergillus niger et Mucor pusillus, mais inhibent la croissance des espèces de moisissures Aspergillus oryzae et Trichoderma viride. Ce type de cuir peut être endommagé aussi par les moisissures du genre Penicillium.

MOTSCLÉS: wet blue, wet white, résistance à la moisissure

\footnotetext{
* Correspondence to: Corina CHIRILĂ, INCDTP - Division: Leather and Footwear Research Institute Bucharest, 93 lon Minulescu st., sector 3, RO-031215 Bucharest, e-mail: corina.chirila@icpi.ro
} 


\section{INTRODUCTION}

Various types of finished leather are very susceptible to fungal attack. The biodeterioration of leather and leather goods includes undesirable and aggressive activities of fungi during leather manufacture, finishing, storage and in use. So, finished leather and leather goods, stored under varying environmental conditions in warehouses, frequently become mouldy. The relative humidity plays an important role.

We are all familiar with the unpleasant situation where our leather shoes, belt, jacket or handbag becomes mouldy (Figure 1). At present, it is known that tanned and finished leather may be damaged by fungi from Aspergillus flavus and Aspergillus niger, Trichoderma viride, Penicillium glaucom and Penicillium cyclopium, and Paecilomyces variotii species, which irreversibly damage leather through the enzymes they produce (collagenases, lipases and proteases). Fungi grow rapidly under high humidity conditions and at temperatures ranging from 25 and $30^{\circ} \mathrm{C}$.

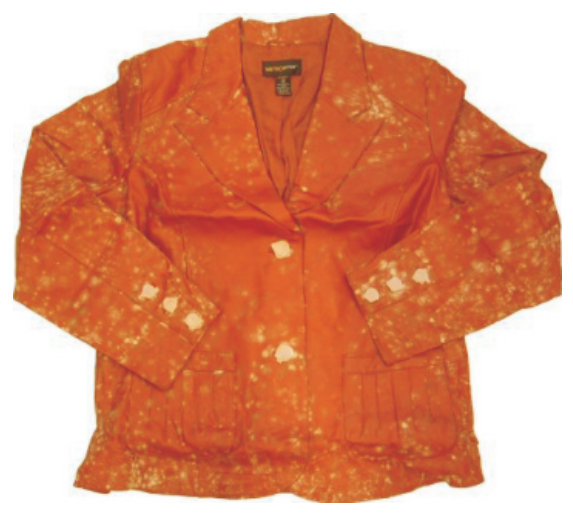

\section{INTRODUCERE}

Diversele tipuri de piele sunt foarte sensibile la atacul fungic. Biodeteriorarea pielii şi a produselor din piele cuprinde şi activitatea indezirabilă şi agresivă a mucegaiurilor în timpul fabricării, finisării, depozitării şi utilizării pieilor. Astfel, pielea şi produsele din piele, depozitate în diverse condiţii ambientale în depozite, mucegăiesc în mod frecvent. Umiditatea relativă joacă un rol important.

$\mathrm{Cu}$ toţii cunoaştem situaţia neplăcută în care pantofii, cureaua, geaca sau geanta noastră de piele mucegăieşte (Figura 1). În momentul de faţă se cunoaşte faptul că pieile tăbăcite şi pieile finisate pot fi deteriorate de mucegaiuri din speciile Aspergillus flavus şi Aspergillus niger, Trichoderma viride, Penicillium glaucom şi Penicillium cyclopium şi Paecilomyces variotii care degradează în mod ireversibil pielea prin enzimele (colagenaze, lipaze şi proteaze) pe care le produc. Mucegaiurile au o creştere rapidă în condiţii de umiditate ridicată şi temperaturi între 25 şi $30^{\circ} \mathrm{C}$.

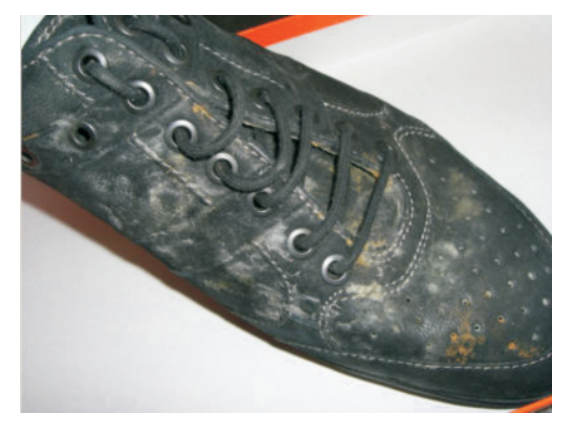

Figure 1. Fungi infested leather goods [1, 2]

Figura 1. Produse din piele mucegăite $[1,2]$

The most common fungi found on leather are Aspergillus niger and Aspergillus flavus (Figure 2), moulds that, in addition to the destructive effect they have on leather objects, are also harmful for human health. Aspergillus flavus is dangerous because of the alfatoxin it produces, one of the most carcinogenic substances in the living world, while Aspergillus niger
Cele mai răspândite mucegaiuri întâlnite pe piei sunt Aspergillus niger şi Aspergillus flavus (Figura 2), mucegaiuri care, pe lângă efectul distructiv pe care îl au asupra obiectelor din piele, sunt dăunătoare şi pentru sănătatea omului. Aspergillus flavus este periculos prin alfatoxina pe care o produce, aceasta fiind una dintre cele mai cancerigene substanţe din lumea vie, în timp 
may cause aspergillosis in immunocompromised patients. ce Aspergillus niger poate produce aspergiloza la pacienţii imuno-compromişi.

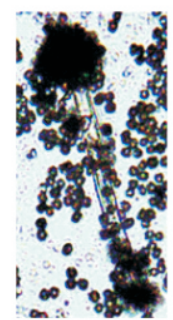

A

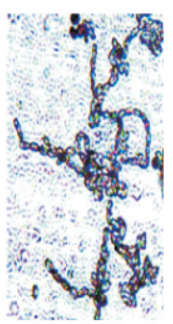

$\mathrm{B}$
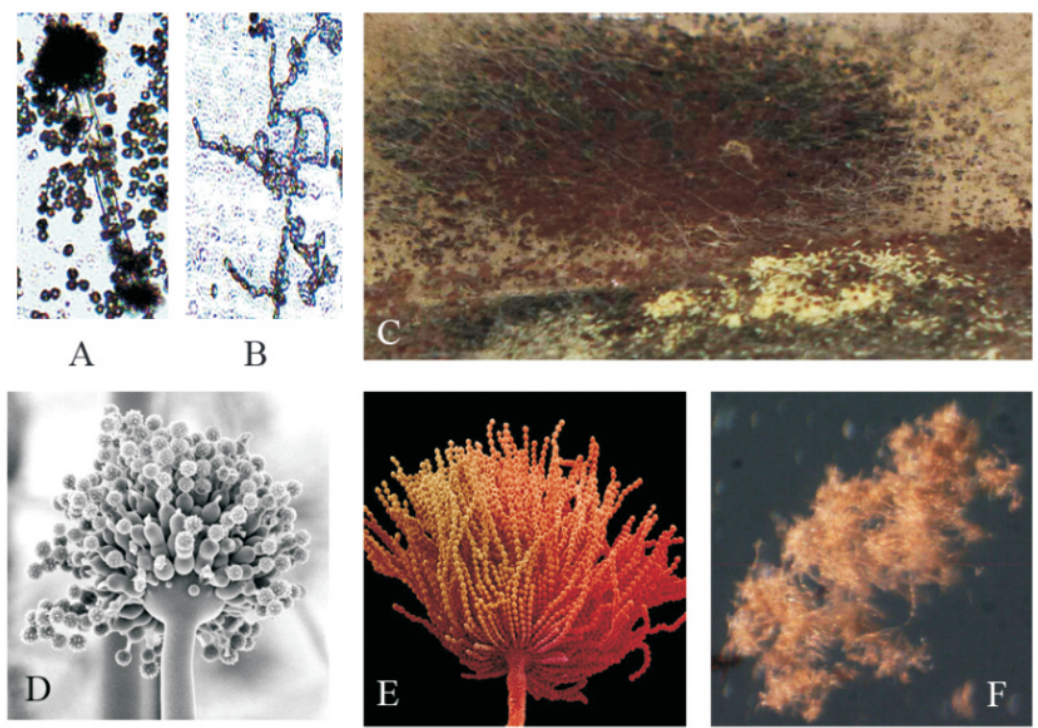

Figure 2. Aspergillus niger and Aspergillus flavus: A - Microscopic appearance of Aspergillus niger spores;

B - Microscopic appearance of Aspergillus flavus spores; C - Aspergillus niger and flavus colonies on a leather sample; D - Aspergillus niger fruiting body; E - Aspergillus flavus fruiting body;

\section{$\mathrm{F}$ - Aspergillus flavus, microscopic appearance}

Figura 2. Aspergillus niger şi Aspergillus flavus: A - Aspectul microscopic al sporilor de Aspergillus niger;

B - Aspectul microscopic al sporilor de Aspergillus flavus; C - Colonii de Aspergillus niger şi flavus pe o probă de piele; D - Corp de fructificaţie Aspergillus niger; E - Corp de fructificaţie Aspergillus flavus;

$\mathrm{F}$ - Aspergillus flavus, aspect microscopic

Aspergillus niger is a widespread mould in the environment which may develop on almost anything: coffee, various foods, textiles, wood, paper and leather goods, which is why this mould was used to test resistance of leather to fungi. Mould is invasive, developing quicker than Penicillium or other types of fungi, with the tendency of extending to the detriment of other species.

Aspergillus niger strain ATCC 6275 (Figure 3) was first isolated in a laboratory in The United States, from a leather sample. The strain is characterized by the presence of genes for carboxymethyl cellulase, citric acid, glucosidase, xylanase, lipases and resistance to copper.

Trichoderma viride (Figure 4) is a green coloured mould used in the antifungal treatment of soil and seeds due to its ability to inhibit growth of other fungi, but can also be pathogenic for certain plants, such as
Aspergillus niger este un mucegai foarte răspândit în mediul înconjurător, care se poate dezvolta pe aproape orice: cafea, diverse alimente, materiale textile, lemn, hârtie şi obiecte confecţionate din piele, motiv pentru care a fost folosit acest mucegai pentru testarea rezistenţei fungice a pieilor. Mucegaiul are un caracter invaziv, dezvoltându-se mai repede decât Penicillium sau alte genuri de mucegai şi având tendinţa de a se extinde în detrimentul altor specii.

Tulpina ATCC 6275 (Figura 3) de Aspergillus niger a fost izolată prima dată într-un laborator din Statele Unite ale Americii de pe o probă de piele. Tulpina este caracterizată prin prezenţa genelor pentru carboximetilcelulază, acid citric, glucosidază, xilanază, lipaze şi rezistenţă la cupru.

Trichoderma viride (Figura 4) este un mucegai de culoare verde folosit în tratamentul antifungic al solului şi al seminţelor datorită capacităţii sale de a inhiba creşterea altor mucegaiuri, dar poate fi şi patogen 
onion. The mould produces cellulases and chitinases and develops on wood and parasitizing other fungi, which is why it damages mushrooms. This mould may also grow on tanned leather.

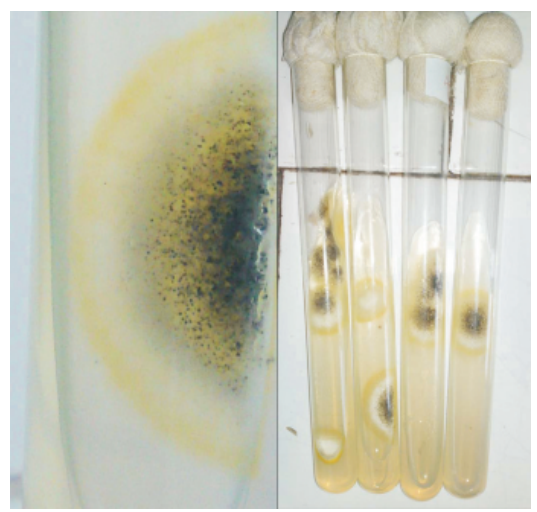

Figure 3. Aspergillus niger cultures, strain ATCC 6275 Figura 3. Culturi de Aspergillus niger, tulpina ATCC 6275 pentru anumite plante, din care amintim ceapa. Mucegaiul produce celulaze şi chitinaze şi se dezvoltă atât pe lemn, cât şi parazitând alţi fungi şi, din acest motiv, este dăunător pentru ciupercile de crescătorie. Acest mucegai poate creşte şi pe pieile tăbăcite.

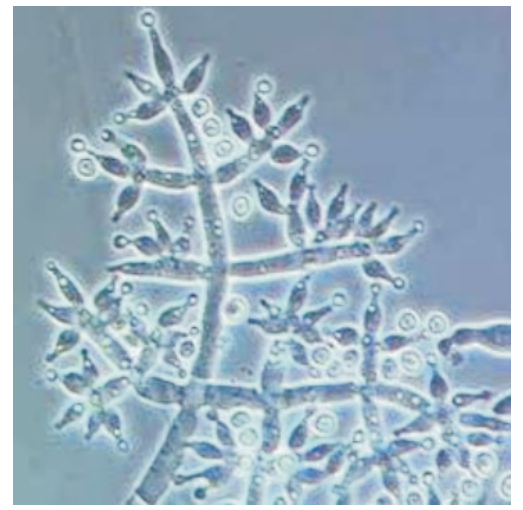

Figure 4. Trichoderma viride

Figura 4. Trichoderma viride

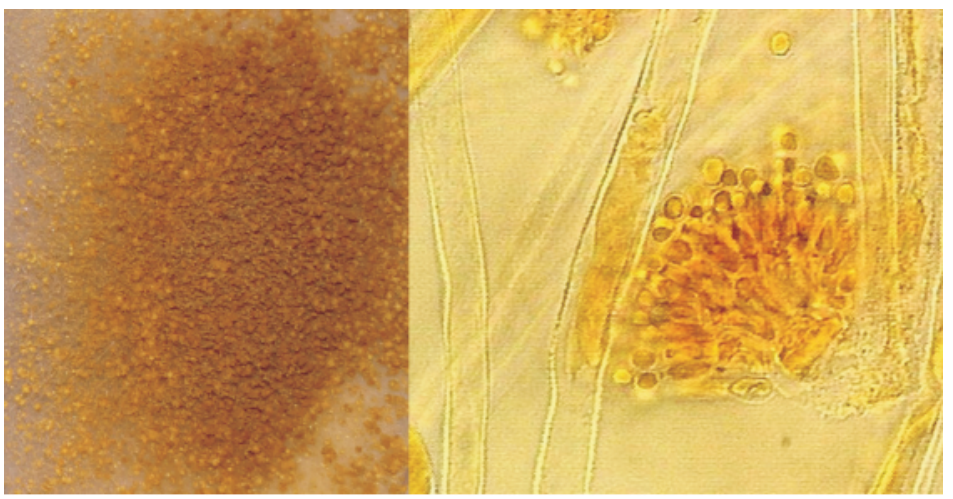

Figure 5. Aspergillus oryzae, colony and microscopic appearance

Figura 5. Aspergillus oryzae, colonie şi aspect microscopic

Aspergillus oryzae (Figure 5) is characterized by the presence of orange globular conidia, and it is used in Asian cuisine for soybean fermentation. The mould produces amylases and carboxypeptidases. Unlike Aspergillus flavus and Aspergillus niger, Aspergillus oryzae has not been identified on leather so far, but the possibility of its development on chromium-free tanned leather samples was taken into account.
Aspergillus oryzae (Figura 5) este un mucegai caracterizat prin prezenţa conidiilor globulare de culoare portocalie, folosit în bucătăria asiatică pentru fermentarea boabelor de soia. Mucegaiul produce amilaze şi carboxipeptidaze. Spre deosebire de Aspergillus flavus şi Aspergillus niger, Aspergillus oryzae nu a fost identificat până acum pe piei, dar s-a urmărit posibilitatea de a se dezvolta pe probele de piele tăbăcită fără crom. 


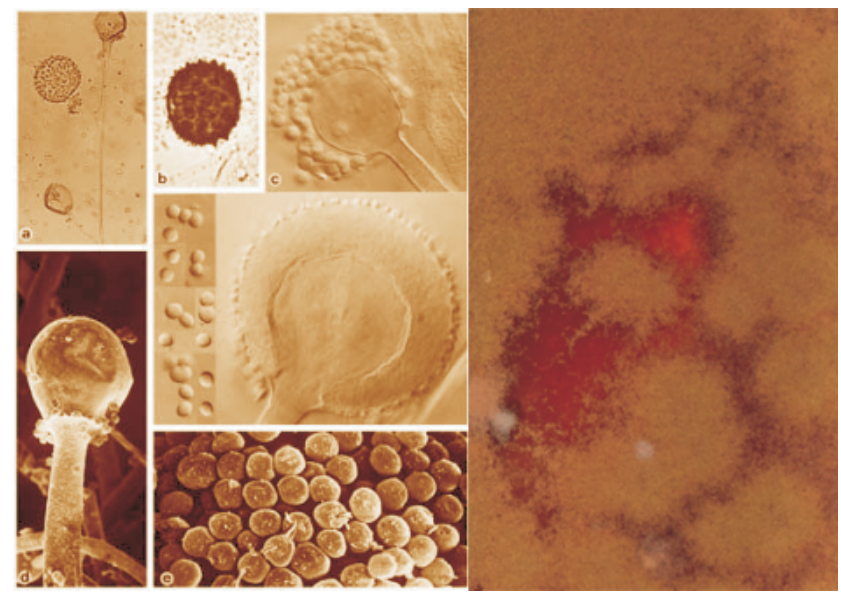

Figure 6. Mucor pusillus, microscopic and macroscopic appearance

Figura 6. Mucor pusillus, aspect microscopic şi macroscopic

Mucor pusillus (Figure 6) develops in soils and decomposes organic matter of vegetable origin. No growth of this mould has been yet reported on tanned leather, but this study aimed at discovering whether fungi can damage wet-blue and wet-white tanned leather through the proteases they produce.

At present, chrome tanning is the most widely used technique for leather tannage, accounting for more than $90 \%$ of leathers tanned worldwide. However, chrome tannage involves serious environmental risks resulting from the possible oxidation of chromium to a hexavalent state, although tanners are aware of the carcinogenic effect, in accordance with the International Agency for Research on Cancer (IARC) [3]. For this reason, the market has shown a growing demand for "ecological" products, especially regarding the development of tanning processes using alternative tanning agents different from chromium.

Alternative free of chrome (FOC) tanning technologies include the use of tanning agents based of titanium-aluminum or organic compounds like oxazolidine, which in combination with other retanning agents of vegetable or synthetic origin, allow for obtaining quality leathers that may be used by footwear and upholstery industries.

Wet-blue refers to partially processed leathers that have been tanned with chromium but not dyed, dried or fat-liquored yet. Wet-white refers to partially processed leathers that have been tanned with
Mucor pusillus (Figura 6) se dezvoltă în soluri şi descompune materia organică de origine vegetală. Până acum nu s-au raportat creşteri ale acestui mucegai pe piei tăbăcite, dar prin prezentul studiu s-a urmărit dacă fungii pot deteriora pieile tăbăcite wetblue şi wet-white prin proteazele pe care le produc.

În prezent, tăbăcirea în crom este cel mai frecvent utilizată tehnică pentru tăbăcirea pieilor, reprezentând peste $90 \%$ din pieile tăbăcite la nivel global. Cu toate acestea, tăbăcirea în crom implică riscuri grave de mediu ca urmare a posibilei oxidări a cromului în stare hexavalentă, deşi tăbăcarii sunt conştienţi de efectul cancerigen, potrivit Agenţiei Internaţionale pentru Cercetarea Cancerului (IARC) [3]. Din acest motiv, piaţa a cunoscut o cerere din ce în ce mai mare de produse „ecologice”, mai ales în ceea ce priveşte dezvoltarea unor procese de tăbăcire care utilizează agenţi tananţi alternativi, diferiţi de cei pe bază de crom.

Tehnologiile de tăbăcire alternative fără crom (free-of-chrome, FOC) cuprind utilizarea unor agenţi tananţi pe bază de titan-aluminiu sau compuşi organici precum oxazolidina, care, în combinaţie cu alţi agenţi de retăbăcire de origine vegetală sau sintetică, permite obţinerea unor piei de calitate care pot fi utilizate în industriile de fabricare a încălţămintei şi de tapiţerie.

Termenul wet-blue se referă la pieile parţial prelucrate care au fost tăbăcite cu crom, dar nu au fost încă vopsite, uscate sau unse. Termenul wet-white se referă la pieile parţial prelucrate care au fost tăbăcite cu 
titanium and/or aluminium or resorcinol/oxazolidine, but not dyed, dried or fat-liquored yet.

This study aims at testing fungal resistance of wet blue leather (chromium-tanned) [4, 5] and of two types of wet white leather tanned with titaniumaluminium [2, 6-13], and with resorcinol-oxazolidine, respectively [14-19].

\section{MATERIALS AND METHODS}

\section{Materials}

Specimens of leather were obtained from tanning stage: wet-blue (chrome tanned), Ti-Al tanned wetwhite [20] and resorcinol-oxazolidine tanned wetwhite [14].

Biological material: 4 fungi strains were used: Aspergillus niger ATCC 6275, Trichoderma viride, Aspergillus oryzae 153 and Mucor pusillus.

Culture medium: Potato Dextrose Agar (PDA) culture medium was used.

\section{Methods}

Microbiological tests were performed according to ASTM standard D 4576-08 (2013) - Test Method for Mold Growth Resistance of Wet Blue. Four samples of each type of leather were inoculated with each of the 4 fungi strains and were incubated at $28 \pm 1^{\circ} \mathrm{C}$ for 28 days. Leather samples were evaluated after 7, 14, 21 and 28 days to determine fungi growth, ranking them from 0 to 4.

Leather samples were regularly checked every 7 days to see whether mould has grown on their surface. Fungal resistance was assessed by ranking samples from 0 to 4, depending on the fungal growth, as follows: mark 0 for leathers not covered by mould, mark 0.5 for growth on less than $12 \%$ of the sample surface, mark 1 for growth ranging between 12 and $25 \%$ of the surface, mark 2 if $50 \%$ of the sample surface is covered by fungi, mark 3 if mould grew on $75 \%$ of the sample surface and mark 4 if the sample is entirely covered by mould.

Chemical tests of wet-blue and wet-white leathers were performed according to EN ISO standards. titan şi/sau aluminiu sau rezorcină/oxazolidină, dar nu au fost încă vopsite, uscate sau unse.

Prezentul studiu are ca scop testarea rezistenţei fungice a pieilor wet blue (tăbăcite cu crom) $[4,5]$ şi a două tipuri de piei wet white tăbăcite cu titan-aluminiu [2, 6-13], respectiv cu rezorcină-oxazolidină [14-19].

\section{MATERIALE ŞI METODE}

\section{Materiale}

Probe de piei tăbăcite în diferite moduri: probe de piele wet-blue (tăbăcite cu crom), probe de piele wetwhite tăbăcite cu agenţi tananţi pe bază de Ti-Al [20] şi probe de piele wet-white tăbăcite organic cu rezorcinăoxazolidină [14].

Material biologic: S-au folosit 4 tulpini de mucegai: ATCC 6275 de Aspergillus niger, Trichoderma viride, Aspergillus oryzae 153 şi Mucor pusillus.

Mediul de cultură: S-a folosit mediul de cultură pe bază de cartof Potato Dextrose Agar (PDA).

\section{Metode}

Testele microbiologice s-au efectuat conform ASTM standard D 4576-08 (2013) - Metoda de testare a rezistenţei la mucegai a pieilor wet-blue. Câte 4 probe din fiecare tip de piele au fost inoculate cu fiecare din cele 4 tulpini de mucegai şi au fost incubate la $28 \pm 1^{\circ} \mathrm{C}$ pentru 28 de zile. Probele de piele au fost evaluate după 7, 14, 21 şi 28 de zile privind creşterea mucegaiului, prin acordarea unor note de la 0 la 4.

S-au efectuat verificări regulate la intervale de 7 zile pentru a observa creşterea mucegaiului pe probele de piele. Evaluarea rezistenţei la mucegai s-a efectuat prin acordarea unor note de la 0 la 4 în funcţie de răspândirea mucegaiului, astfel: nota 0 pentru pieile neacoperite de mucegai, nota 0.5 pentru creşteri pe mai puţin de $12 \%$ din suprafaţa probei, nota 1 pentru creşteri între 12 şi $25 \%$ din suprafaţă, nota 2 dacă $50 \%$ din suprafaţa probei este acoperită de mucegai, nota 3 dacă mucegaiul a crescut pe $75 \%$ din suprafaţa probei şi nota 4 dacă proba este acoperită în întregime de mucegai.

Testele chimice ale pieilor wet-blue şi wet-white s-au efectuat conform standardelor EN ISO în vigoare. 


\section{RESULTS AND DISCUSSIONS}

Wet-blue and wet-white leathers are excellent substrates for fungal growth: storage temperature, acid $\mathrm{pH}$, presence of water, proteins and fats constitute the most important conditions for the development and growth for a lot of moulds, such as Penicillium spp., Aspergillus spp. and Trichoderma viride. The fungal contamination appears as coloured stains on the leather, usually permanent.

Chemical characteristics of wet-blue and wetwhite leather are shown in Table 1.

\section{REZULTATE ŞI DISCUTII}

Pieile wet-blue şi wet-white sunt substraturi excelente pentru creşterea mucegaiului: temperatura de depozitare, $\mathrm{pH}$ acid, prezenţa apei, proteinele şi grăsimile constituie cele mai importante condiţii pentru dezvoltarea şi creşterea mucegaiurilor precum cele din speciile Penicillium, Aspergillus şi Trichoderma viride. Contaminarea cu mucegai are aspectul unor pete colorate pe piele şi sunt, de regulă, permanente.

Caracteristicile chimice ale pieilor wet-blue şi wetwhite luate în studiu sunt prezentate în Tabelul 1.

Table 1: Wet-blue and wet-white leather characteristics

Tabelul 1: Caracteristicile pieilor wet-blue şi wet-white

\begin{tabular}{|c|c|c|c|c|}
\hline $\begin{array}{l}\text { No. } \\
\text { Nr. } \\
\text { crt. }\end{array}$ & $\begin{array}{l}\text { Characteristics } \\
\text { Caracteristici }\end{array}$ & $\begin{array}{l}\text { Wet-blue } \\
\text { Wet-blue }\end{array}$ & $\begin{array}{l}\text { Wet-white } \\
\text { Ti-Al tanned } \\
\text { Wet-white } \\
\text { tăbăcită cu Ti-Al }\end{array}$ & $\begin{array}{l}\text { Wet-white } \\
\text { organic tanned } \\
\text { Wet-white } \\
\text { tăbăcită organic }\end{array}$ \\
\hline 1 & $\begin{array}{c}\text { Chrome oxide, \% } \\
\text { Oxid de crom, \% }\end{array}$ & 3.5 & 0 & 0 \\
\hline 2 & $\begin{array}{l}\text { Ti/Al oxides, \% } \\
\text { Oxizi Ti/Al, \% }\end{array}$ & 0 & 3.12 & 0 \\
\hline 3 & $\begin{array}{l}\text { Shrinkage temperature, }{ }^{\circ} \mathrm{C} \\
\text { Temperatura de contracţie, }{ }^{\circ} \mathrm{C}\end{array}$ & $\begin{array}{l}\text { Over } 100 \\
\text { Peste } 100\end{array}$ & $75-78$ & $70-74$ \\
\hline 4 & $\begin{array}{c}\text { Grease, } \% \\
\text { Substanţe grase, } \%\end{array}$ & 1.2 & 2.1 & 4.5 \\
\hline 5 & $\begin{array}{l}\mathrm{pH} \\
\mathrm{pH}\end{array}$ & 3.5 & 3.6 & 4.3 \\
\hline 6 & $\begin{array}{l}\text { Moisture, } \% \\
\text { Umiditate, \% }\end{array}$ & 59.0 & 66.33 & 55.0 \\
\hline 7 & $\begin{array}{c}\text { Ash, \% } \\
\text { Cenuşă, \% }\end{array}$ & 16.6 & 12.59 & 10.5 \\
\hline 8 & $\begin{array}{c}\text { Total nitroge } n, \% \\
\text { Azot total, } \%\end{array}$ & 12.7 & 13.84 & 12.9 \\
\hline 9 & $\begin{array}{c}\text { Digestibility, \% } \\
\text { Digestibilitate, \% }\end{array}$ & 51.9 & 61.3 & 65.5 \\
\hline
\end{tabular}

Table 2 presents the appearance and assessment (marks) of leather samples after 7, 14, 21 and 28 days. According to the working standard, samples were evaluated ranking them from 0 to 4 depending on the growth of mould on the sample (Table 2). The following were found:

After 7 days Aspergillus niger grew on the entire surface of the organic tanned wet white leather
În Tabelul 2 sunt redate aspectul şi evaluarea (notele) probelor de piele după 7, 14, 21 şi 28 de zile. Conform standardului de lucru, probele au fost evaluate cu note de la 0 la 4, în funcţie de gradul de creştere a mucegaiului pe probă (Tabel 2). S-au constatat următoarele:

După 7 zile, Aspergillus niger a crescut pe întreaga suprafaţă a probei de piele wet-white tăbăcită organic, 
sample, on approximately $50 \%$ of the chromiumtanned wet-blue leather sample and on less than $25 \%$ of the Ti-Al-tanned leather sample.

Aspergillus oryzae grew on the surface of wetblue leather sample and on the Ti-Al-tanned wet-white leather sample without damaging them. The organic tanned wet-white leather sample inhibited growth.

Trichoderma viride grew in the culture medium, but not on the wet-blue leather sample, while a spontaneous growth of Aspergillus niger appeared on its surface; approximately $10 \%$ of the Ti-Al-tanned wetwhite leather sample is covered by Trichoderma, and the organic tanned wet-white leather sample almost completely inhibited mould growth.

Mucor pusillus only grew in the culture medium around the wet-white leather samples. The wet-blue leather sample completely inhibited mould growth, but was contaminated with Aspergillus niger.

After 14 days, Aspergillus niger grew on all 3 types of leather, the wet-blue sample showing a lower number of conidia on the surface, while Aspergillus oryzae covered the wet-blue and Ti-Al-tanned wetwhite samples almost entirely, but its growth was further inhibited by the wet-white leather sample tanned with resorcinol-oxazolidine.

Trichoderma did not grow on the wet-blue leather sample and did not inhibit the growth of Aspergillus niger colony. The growth of Trichoderma viride colonies was inhibited by the leather sample tanned with resorcinol-oxazolidine, but a colony of Aspergillus niger spontaneously appeared on the sample. Trichoderma viride grew on $75 \%$ of the titanium-aluminium-tanned wet-white leather sample.

The chromium-tanned wet-blue sample completely inhibited the growth of Mucor pusillus colonies. The mould grew neither in the culture medium, nor on the surface of the wet-blue leather sample, but it was entirely covered by Aspergillus niger. Wet-white leather samples were entirely covered by Mucor pusillus. On the Ti-Al-tanned wet-white leather sample inoculated with Mucor pusillus, a colony of Aspergillus flavus also appeared. The colony is very invasive, quickly covering the entire surface of the sample. pe aproximativ $50 \%$ din suprafaţa probei de piele wetblue tăbăcită cu crom şi pe mai puţin de $25 \%$ din suprafaţa probei de piele tăbăcită cu Ti-Al.

Aspergillus oryzae a crescut pe suprafaţa probei de piele wet-blue şi pe suprafaţa probei de piele wetwhite tăbăcită cu Ti-Al fără să le deterioreze. Proba de piele wet-white tăbăcită organic a inhibat creşterea.

Trichoderma viride a crescut în mediul de cultură, dar nu şi pe proba de piele wet-blue, pe suprafaţa acesteia apărând o creştere spontană de Aspergillus niger, proba de piele wet-white tăbăcită cu Ti-Al este acoperită de Trichoderma pe aproximativ 10\% din suprafaţă, iar proba de piele wet-white tăbăcită organic a inhibat aproape total creşterea mucegaiului.

Mucor pusillus nu a crescut decât în mediul de cultură din jurul probelor de piele wet-white. Proba de piele wet-blue a inhibat total creşterea mucegaiului, dar a fost contaminată cu Aspergillus niger.

După 14 zile, Aspergillus niger a crescut pe toate cele 3 tipuri de piele, proba de piele wet-blue prezentând un număr mai mic de conidii pe suprafaţă, în timp ce Aspergillus oryzae a acoperit aproape în întregime probele de piele wet-blue şi wet-white tăbăcită cu titan-aluminiu, dar creşterea sa a fost în continuare inhibată de pielea wet-white tăbăcită cu rezorcină-oxazolidină.

Trichoderma nu a crescut pe proba de piele wetblue şi nici nu a inhibat creşterea coloniei de Aspergillus niger. Creşterea coloniilor de Trichoderma viride a fost inhibată de proba de piele tăbăcită organic cu rezorcină-oxazolidină, dar pe respectiva probă a apărut spontan o colonie de Aspergillus niger. Trichoderma viride a crescut pe $75 \%$ din suprafaţa probei de piele wet-white tăbăcită cu titan-aluminiu.

Pielea wet-blue tăbăcită cu crom a inhibat total creşterea coloniilor de Mucor pusillus. Mucegaiul nu a crescut nici în mediul de cultură, nici pe suprafaţa probei de piele wet-blue, dar aceasta a fost acoperită în întregime de Aspergillus niger. Pieile wet-white au fost acoperite în întregime de Mucor pusillus. Pe proba de piele wet-white tăbăcită cu Ti-Al însămânţată cu Mucor pusillus a apărut şi o colonie de Aspergillus flavus. Colonia prezintă un caracter invaziv, acoperind în timp scurt întreaga suprafaţă a probei. 
Table 2: Appearance and assessment of leather samples after 7, 14, 21 and 28 days Tabelul 2: Aspectul şi evaluarea probelor de piele după 7, 14, 21 şi 28 zile

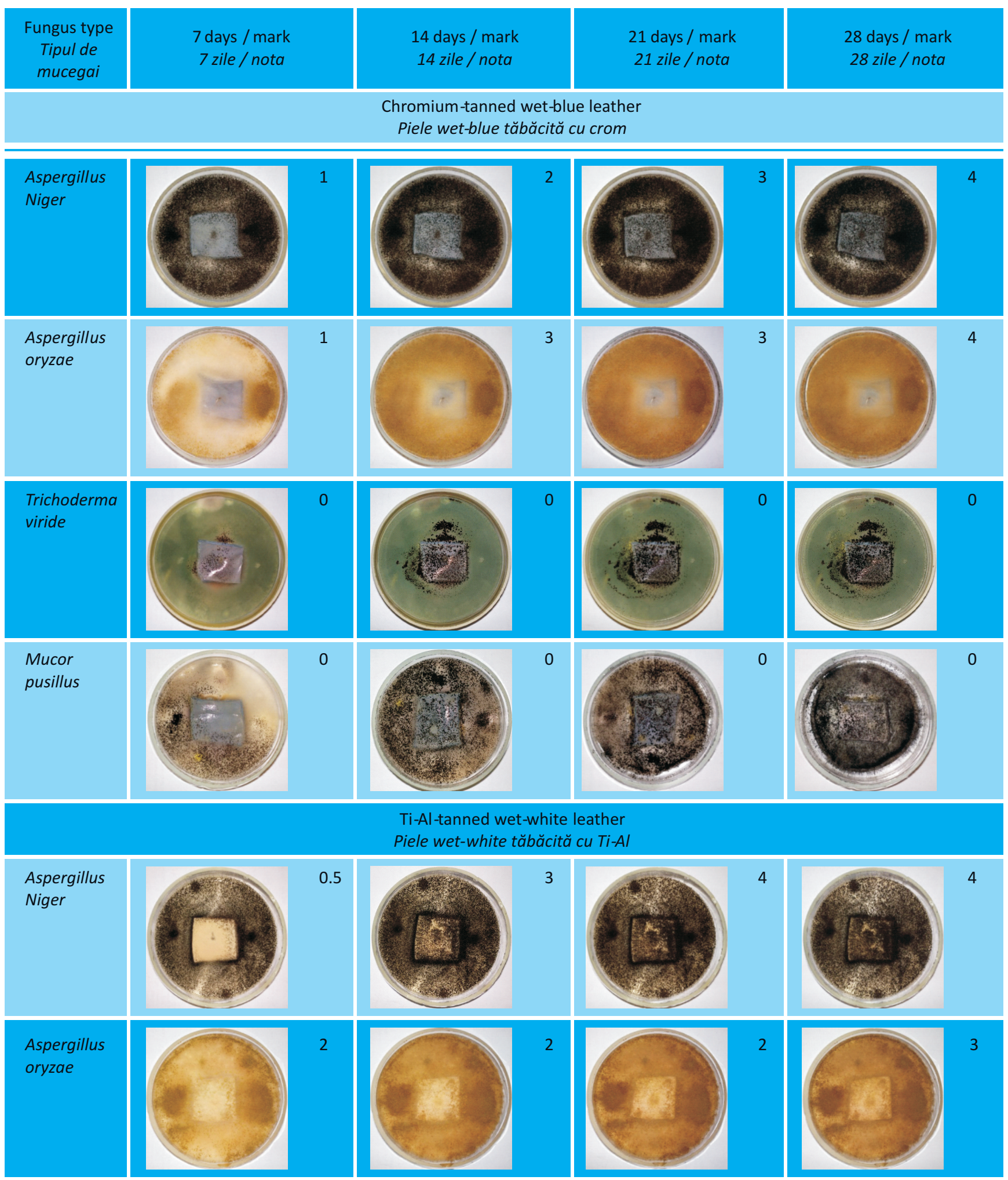


Table 2: Continued

Tabelul 2: Continuare

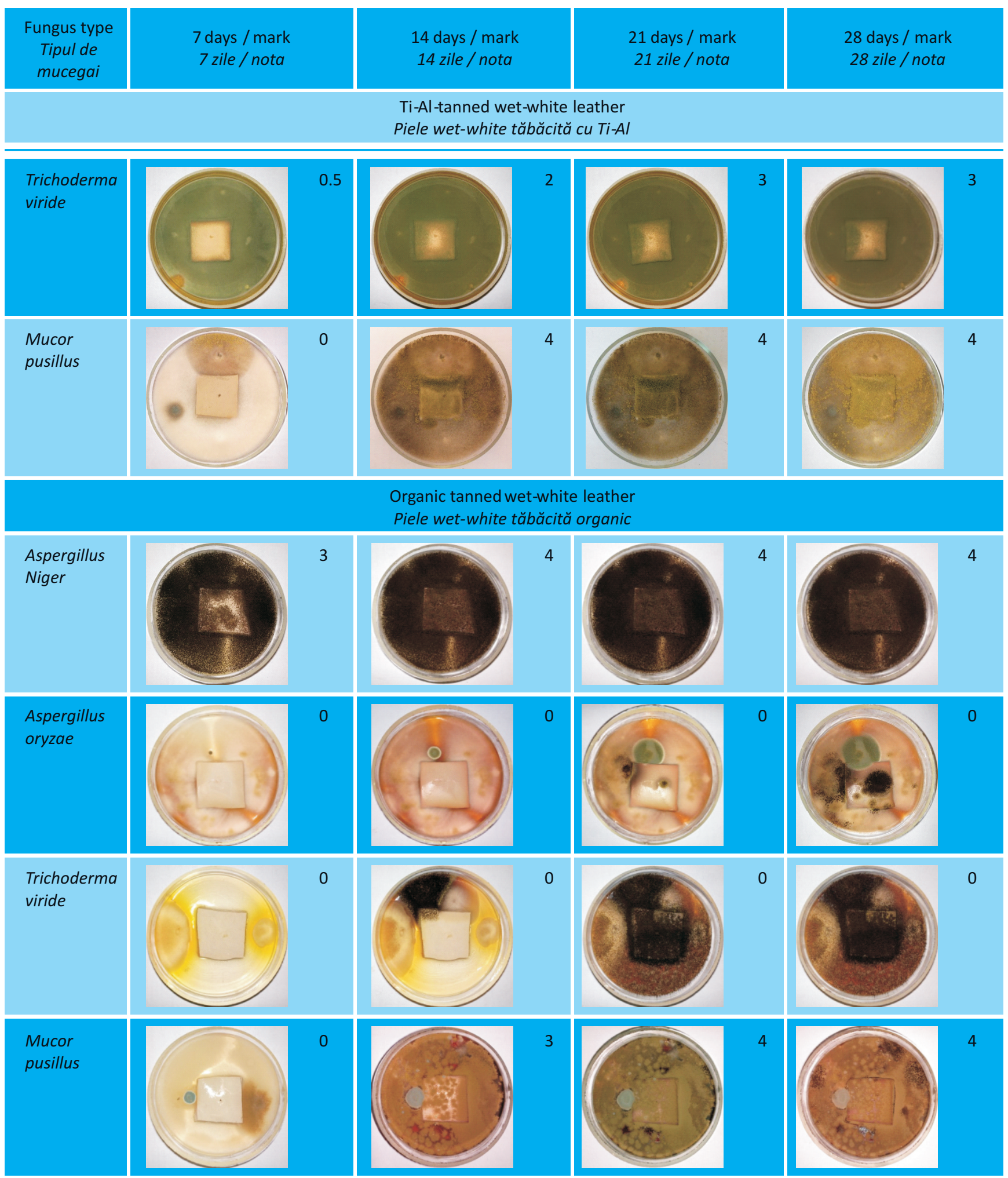




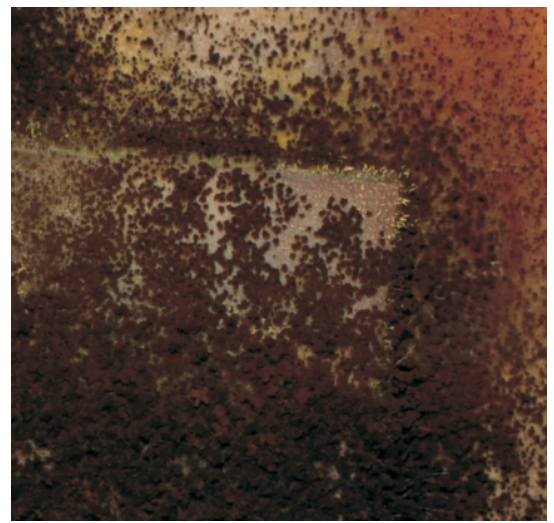

Figure 6. Aspergillus niger and Aspergillus flavus moulds spontaneously grown on the wet-white leather sample tanned with resorcinol-oxazolidine after 21 days

Figura 6. Mucegaiuri din speciile Aspergillus niger şi Aspergillus flavus crescute spontan pe proba de piele wet white tăbăcită cu rezorcină-oxazolidină după 21 de zile

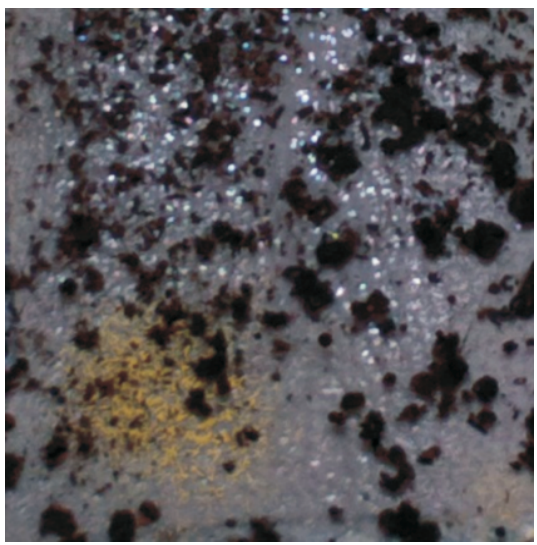

Figure 7. Aspergillus flavus colony spontaneously grown on the wet-blue leather sample initially inoculated with Mucor pusillus

Figura 7. Colonie de Aspergillus flavus crescută spontan pe proba de piele wet blue însămânţată iniţial cu Mucor pusillus

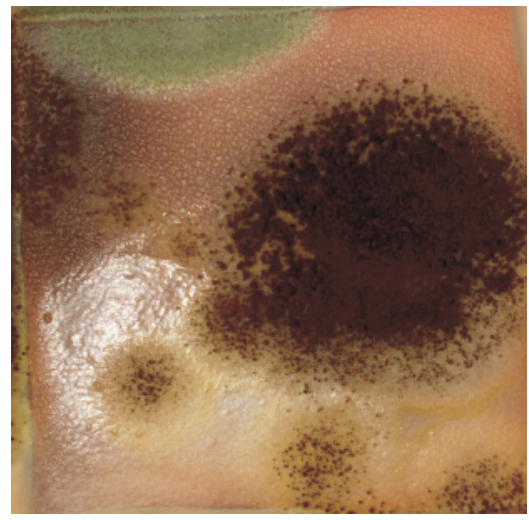

Figure 8. Appearance of the leather sample tabbed with resorcinol-oxazolidine and inoculated with Aspergillus oryzae after 28 days

Figura 8. Aspectul probei de piele tăbăcită cu rezorcină-oxazolidină şi inoculată cu Aspergillus oryzae după 28 de zile

After 21 days, all leather samples inoculated with Aspergillus niger were entirely covered by mould; the situation of samples inoculated with Aspergillus oryzae remained unchanged except for the sample tanned with resorcinol-oxazolidine on which two Aspergillus niger colonies and one Penicillium colony appeared, while the appearance of samples inoculated with Mucor pusillus did not change much. The leather sample tanned with resorcinol-oxazolidine completely
După 21 de zile, toate probele de piele inoculate cu Aspergillus niger au fost acoperite în întregime de mucegai; situaţia probelor inoculate cu Aspergillus oryzae a rămas neschimbată, exceptând proba tăbăcită cu rezorcină-oxazolidină, pe care au apărut două colonii de Aspergillus niger şi o colonie de Penicillium, iar aspectul probelor inoculate cu Mucor pusillus nu s-a schimbat prea mult. Proba de piele tăbăcită organic cu rezorcină-oxazolidină a inhibat total creşterea 
inhibited the growth of Trichoderma viride colonies, but was entirely covered by Aspergillus niger and a colony of Aspergillus flavus also appeared (Figure 6). On the chromium-tanned wet-blue leather sample inoculated with Trichoderma viride, a colony of Aspergillus flavus appeared which also spread on the culture medium, its growth not being inhibited by Trichoderma viride. The appearance of the Ti-Al-tanned wet-white leather sample inoculated with Trichoderma viride did not change much. On the wet-blue sample initially inoculated with Mucor pusillus, a colony of Aspergillus flavus appeared (Figure 7).

After 28 days the appearance of samples inoculated with Aspergillus niger and oryzae did not change, except for the leather sample tanned with resorcinoloxazolidine inoculated with Aspergillus oryzae (Figure 8) on the surface of which a Penicillium colony also grew, while Aspergillus niger colonies developed. The appearance of samples inoculated with Trichoderma viride and Mucor pusillus did not change much either.

\section{CONCLUSIONS}

Aspergillus niger and Aspergillus flavus are the most aggressive and invasive species, developing very rapidly, much quicker than Trichoderma viride, Mucor pusillus and moulds from the Penicillium genus, the latter having the slowest growth rate. Although it produces chitinases with antifungal effect, Trichoderma viride does not inhibit development of Aspergillus niger and flavus species.

It has been concluded by this study that no leather type is completely resistant to fungal attack.

Wet-blue leather is highly susceptible for fungal attack of Aspergillus niger and Aspergillus flavus. Trichoderma viride does not grow on chromiumtanned wet-blue leather samples, but they do not inhibit mould growth in the culture medium, as there are no inhibition areas around the sample. Chromiumtanned leather completely inhibits growth of mould from Mucor pusillus species.

Ti-Al-tanned wet-white leather is attacked by all types of fungi studied. coloniilor de Trichoderma viride, dar a fost acoperită în întregime de Aspergillus niger şi a apărut şi o colonie de Aspergillus flavus (Figura 6). Pe proba de piele wetblue tăbăcită cu crom inoculată cu Trichoderma viride a apărut şi o colonie de Aspergillus flavus, care s-a dezvoltat şi pe mediul de cultură, creşterea nefiind inhibată de Trichoderma viride. Aspectul probei de piele wet-white tăbăcită cu Ti-Al inoculată cu Trichoderma viride nu s-a schimbat prea mult. Pe proba de piele wet-blue însămânţată iniţial cu Mucor pusillus a apărut o colonie de Aspergillus flavus (Figura 7).

După 28 de zile, aspectul probelor inoculate cu Aspergillus niger şi oryzae nu s-a schimbat, exceptând proba de piele tăbăcită cu rezorcină-oxazolidină inoculată cu Aspergillus oryzae (Figura 8), pe suprafaţa căreia a crescut şi o colonie de Penicillium, în timp ce coloniile de Aspergillus niger s-au mărit. Nici aspectul probelor inoculate cu Trichoderma viride şi Mucor pusillus nu s-a schimbat prea mult.

\section{CONCLUZII}

Speciile Aspergillus niger şi Aspergillus flavus sunt cele mai agresive şi cele mai invazive, dezvoltându-se foarte repede, mult mai repede decât Trichoderma viride, Mucor pusillus şi mucegaiurile din genul Penicillium, acestea din urmă având cea mai mică viteză de creştere. Deşi produce chitinaze cu efect antifungic, Trichoderma viride nu inhibă dezvoltarea mucegaiurilor din speciile Aspergillus niger şiflavus.

În urma acestui studiu s-a ajuns la concluzia că niciun tip de piele nu este complet rezistent la atacul fungic.

Pieile wet-blue sunt foarte sensibile la atacul mucegaiurilor Aspergillus niger şi Aspergillus flavus. Trichoderma viride nu se dezvoltă pe pieile wet-blue tăbăcite cu crom, dar acestea nu inhibă dezvoltarea mucegaiului în mediul de cultură, neexistând zone de inhibare în jurul probei. Pieile tăbăcite cu crom inhibă total dezvoltarea mucegaiurilor din specia Mucor pusillus.

Pieile wet-white tăbăcite cu Ti-Al sunt atacate de toate tipurile de fungi luate în studiu. 
Wet-white leather samples tanned with resorcinol-oxazolidine are attacked by Aspergillus niger and Mucor pusillus, but inhibit growth of moulds from Aspergillus oryzae and Trichoderma viride species. This type of leather can also be damaged by mould from the Penicillium genus.

\section{Acknowledgements}

This work has been financed by the European Fund for Regional Development and the Romanian Government in the framework of Sectoral Operational Programme under the project INNOVA-LEATHER: «Innovative technologies for leather sector increasing technological competitiveness by RDI, quality of life and environmental protection" - contract POS CCEAXA 2-O 2.1.2 nr. 242/20.09.2010 ID 638 COD SMIS CSNR 12579.
Pieile wet-white tăbăcite cu rezorcină-oxazolidină sunt atacate de Aspergillus niger şi Mucor pusillus, dar inhibă dezvoltarea mucegaiurilor din speciile Aspergillus oryzae şi Trichoderma viride. Acest tip de piei poate fi deteriorat şi de mucegaiuri din genul Penicillium.

Mulţumiri

Această lucrare a fost finanţată de către Fondul European de Dezvoltare Regională şi de către Guvernul României în cadrul Programului Operaţional Sectorial, prin proiectul INNOVA-LEATHER: «Tehnologii inovative pentru sectorul de pielărie care să asigure creşterea competitivităţii prin CDI, calităţii vieţii şi protecţia mediului» - contract POS CCE-AXA 2O 2.1.2 nr. 242/20.09.2010 ID 638 COD SMIS - CSNR 12579 .

\section{REFERENCES}

1. www.lanxessleather.com

2. http://www.leatherusa.org/i4a/pages/index.cfm?pageid=1

3. http://www.iarc.fr/index.php

4. Târlea, M.M., Mutlu, M.M., Macovescu, G., Radulescu, C.H., Adigüzel Zengin, A.C., Bitlisli, B.O., Başaran, B., Antifungal compounds for leather part II. Testing of antifungal activity on bovine leathers, Revista de Pielarie Incaltaminte, 2009, 9, 4.

5. Padoan, K., IULTCS II EUROCONGRESS Istanbul, 2006.

6. Crudu, M., Deselnicu, V., loannidis, I., Deselnicu, D.C., New tanning technologies based on valorization of industrial wastes, The 3rd International Conference on Industrial and Hazardous Waste Management CRETE 2012, Chania, Crete, 2012.

7. Crudu, M., Deselnicu, V., Deselnicu, D.C., Albu, F.L., Valorization of titanium metal wastes as tanning agent used in leather industry, Waste Manag, 2014, ISSN 0956-053X; http://dx.doi.org/10.1016/j.wasman.2013.12.015

8. M. Crudu, Deselnicu, V., loannidis, I., Crudu, A., New wet white tanning Agents and Technology, Proceedings of ICAMS 2012, 27-29 September 2012, Bucharest, RO, 27-34.

9. Crudu, M., Sibiescu, S., Sutiman, D., Cailean, A., loanid, A., Boca, N., Crudu, A., New tanning coordination compounds of $\mathrm{Ti}(\mathrm{IV})$ and $\mathrm{Zr}$ (IV) Part I - Compounds of Ti(IV) and Zr(IV) with N-hydroxysuccinimide as ligand, Revista de Pielarie Incaltaminte, 2010, 10, 1.

10. Kleban, M., Chrome-free Waterproof Leather, US Pat. Appl. No. 200601151738.

11. Adiguzel Zengin, A.C., Crudu, M., Maier, S.S., Deselnicu, V., Albu, L., Gulumser, G., Bitlisli, B.O., Basaran, B., Mutlu, M.M., Eco-leather: Chromium-free Leather Production Using Titanium, Oligomeric Melamine-Formaldehyde Resin, and Resorcinol Tanning Agents and the Properties of the Resulting Leathers, Ekoloji, 2012, 21, 82, 17-25, doi: 10.5053/ekoloji.2011.823

12. Mutlu, M.M., Adiguzel Zengin, A.C., Crudu, M., Maier, S.S., Deselnicu, V., Albu, L., Gulumser, G., Bitlisli, B.O., Basaran, Tosun, C.C., Properties of Leathers Tanned with Ti-Al Based Tanning Materials Obtained From the Wastes of 
Metal Industry, Proceedings of ICAMS 2012, 27-29 September 2012, Bucharest, RO, 147-152.

13. Hancock, R.A., Orszulik, S.T., Sykes, R.L., Tannage with Aluminum salts. Part 2. Chemical basis of the reactions with polyphenols, J. Soc. Leather Technol. Chem., 1980, 64, 2, 32.

14. Deselnicu, V., Crudu, M., Ioannidis, I., Deselnicu, D.C., Innovative organic tanning for leather, International Scientific Conference "Innovative solutions for sustainable development of textiles and leather industry", Oradea, Romania, 2012, Annals of the University of Oradea fascicle of textiles, Leatherwork, Vol. XIII, 2012, No. 1, 226-229, ISSN 1843-813X.

15. Deselnicu, V., Crudu, M., Ioannidis, I., Deselnicu, D.C., Approaches to reducing heavy metal discharges in tannery effluent, The 3rd International Conference on Industrial and Hazardous Waste Management CRETE 2012, Chania, Crete, 2012.

16. Liu, Y. et al., An Environmentally Friendly Leather-Making Process Based on Silica Chemistry J. Am. Leather Chem. Assoc., 2010, 105.

17. Platon, F., Deselnicu, V., Crudu, M., Albu, F.L., Patent RO 123001 B1, 2010, Process for treating animal raw hides.

18. Roig, M., Segarra, V., Bertazzo, M., Martinez, M.A., Ferrer, J., Raspi, C., Chrome-free leather, tanned with oxazolidine, Proceedings of XXXI IULTCS Congress, Valencia, 2011.

19. Deselnicu, V., Crudu, M., Albu, L., Deselnicu, D.C., Crudu, A.M., RO Patent appl. No. A00212/2014, Organic tanning for obtaining wet-white leather.

20. Crudu, M., Deselnicu, V., Ioannidis, I., Deselnicu, D.C., Crudu, A.M., Patent RO 127529B1 - Tanning Composition and process for tanning bovine hides, 2013.

Article received/Data primirii articolului: 23.05.2014

Accepted/Acceptat la data: 16.06.2014 